\title{
Heterosis Studies for Yield and its Components in Tomato (Solanum lycopersicum L.) under North Western Himalayan Region, India
}

\author{
Nidhish Gautam ${ }^{*}$, Manish Kumar ${ }^{2}$, Amit Vikram³, Sandeep Kumar ${ }^{1}$ \\ and Shikha Sharma ${ }^{4}$ \\ ${ }^{1}$ ICAR-IARI, Regional Station -Katrain (Kullu valley) - 175129, India \\ ${ }^{2}$ Department of Seed Science and Technology, \\ ${ }^{3}$ Department of Vegetable Science, ${ }^{4}$ Department of Biotechnology, Dr YS Parmar UHF, \\ Nauni, Solan 173230 (H.P.), India \\ *Corresponding author
}

\section{A B S T R A C T}

\section{Keywords \\ Diallel, Solanum lycopersicum L., Heterosis, Yield and yield components \\ Article Info \\ Accepted: \\ 17 January 2018 \\ Available Online: \\ 10 February 2018}

A $6 x 6$ diallel cross excluding reciprocal of tomato was evaluated with parents for heterotic manifestation of yield and yield attributing characters. The heterosis over better parent (BP) to the extent of $-14.64,-7.70,15.84,21.29,15.30$ and 38.91 per cent was recorded for days to first flowering, days to marketable maturity, average fruit weight, number of fruit per plant, harvest duration, yield per hectare, and plant height , respectively. The crosses showing heterosis for yield per plant were not heterotic for all the characters under study. The heterosis for yield was generally accompanied by heterosis for yield components. Three promising crosses viz., UHFT-9 x Solan Lalima, UHFT-10 x Solan Lalima, and UHFT-22 x Solan Lalima were identified for developing high yielding $\mathrm{F}_{1}$ hybrids/ varieties of tomato with many desirable horticultural traits.

\section{Introduction}

Plant breeders have extensively explored and utilized heterosis to boost yield levels in several cross-pollinated crops in the recent past. However, tomato being a highly selfpollinated species, the scope for exploitation of hybrid vigour depends on the direction and magnitude of heterosis, and ease with which hybrid seeds can be produced. Commercial exploitation of hybrid vigour in tomato has received greater importance on account of several advantages of hybrids over pure line varieties with resistance/tolerance to biotic and abiotic stresses. Hence, identification of high yielding and stable varieties and the development of $F_{1}$ hybrids will help the farmers to adopt variety/hybrid for successful commercial cultivation of tomato. The reproductive biology and production of appreciable quantity of seeds per fruit provide plentiful opportunity for manifestation of heterosis in tomato (Singh and Singh, 1993). Heterosis in tomato was first observed by Hedrick and Booth (1968) for higher yield and more number of fruits. Since then, 
heterosis for yield, its components and quality traits were extensively studied (Ahmad et al. 2011; Kurian et al. 2011). Choudhary et al. (1965) emphasized the extensive utilization of heterosis to step-up the tomato production but the tomato hybrid performed differently under the different agro climatic conditions. Present investigation was undertaken to ascertain the nature and extent of heterosis for yield and its component characters in tomato.

\section{Materials and Methods}

Six tomato lines viz., UHFT-22, UHFT-55, UHFT-9, UHFT-10, EC-2798 and Solan Lalima were crossed in diallel fashion (excluding reciprocals) following Griffing (1956). The 21 genotypes (15 direct $F_{1}$ crosses +6 parents) were grown in Experimental Research Farm, Department of Vegetable Science, Dr Y. S. Parmar, UHF, Nauni, Solan (HP), India following randomized complete block design with 3 replications during 2012-13.

Twenty eight days old nursery seedlings were transplanted at a distance of $90 \mathrm{~cm} \times 30 \mathrm{~cm}$. Twelve plants of each genotype per replication were grown by adopting standard agronomic practices to maintain healthy crop stand. The data were recorded on days to first flowering, days to marketable maturity, number of fruits per plant, fruit weight $(\mathrm{g})$, fruit yield per hactare (q) and plant height (cm). Analysis of variance was performed according to Gomez and Gomez (1983). Heterosis over better parent and check for different characters under study were calculated as per standard procedures.

\section{Results and Discussion}

Analysis of variance indicated significant differences among genotypes for the various characters analyzed (Table 1). The magnitude of heterosis for different characters under study among the hybrid combinations are presented in Table 1 to 5.

\section{Days to first flowering}

Earliness is important to fetch premium prices in a market and hybrids being early are preferred over pure line varieties in tomato. Therefore, days to first flowering are primary indicator to predict earliness in a crop like tomato. Heterosis studies revealed that three cross combinations viz., UHFT-55 x EC-2798 (-14.64), UHFT-55 x UHFT-10 (-7.26) and UHFT-55 x Solan Lalima (-6.38) showed significant negative heterosis over better parent. Further, the cross UHFT-22 x Solan Lalima showed highest significant negative heterosis over check Naveen and can be a better alternative for earliness. Early flowering in hybrids has also been reported by Mirshamssi et al. (2006), Hannan et al. (2007), Kumari et al. (2010) and Kumari and Sharma (2011).

\section{Days to marketable maturity}

Commonly varieties/hybrids may flower early but availability of produce is not maturing hence, days to marketable maturity provides more realistic estimates for deciding the maturity period of a variety. The three cross combinations viz., UHFT-55 x EC-2798 (7.70), UHFT-55 x UHFT-10(-5.23) and UHFT-55 x Solan Lalima (-3.29) resulted in significant negative heterosis over better parent. Cross combination UHFT-22 x Solan Lalima (-7.68) revealed highest negative heterosis over check cultivar. Negative heterobeltiosis for earliness has also been reported by Kumar et al. (2009), Kumari et al. (2010) and Singh and Sastry (2011).

\section{Average fruit weight (g)}

Average fruit weight has direct contribution to yield. The seven cross combinations 
resulted in significant positive heterosis over better parent and UHF-10 x EC-2798(15.84), UHFT-22 x EC-2798 (15.68), UHFT-9 x UHFT-10 (8.10), and UHFT-55 x EC-2798 (7.74) were the top four crosses. Significant positive heterosis over the check was revealed by the two cross combinations viz., UHFT $-9 x$ Solan Lalima (9.53) and UHFT-9 x UHFT-10 (4.65). The studies corroborate with the findings of Kumar et al. (2009), Kumari et al. (2010), Gul et al. (2010), Ahmed et al. (2011), Singh and Sastry (2011) and Kumari and Sharma (2011).

\section{Number of fruits per plant}

Number of fruits per plant is the most important component trait which is directly related to increased fruit yield per plant. Among all the crosses, ten cross combinations resulted in significant positive heterosis over better parent. whereas, significant positive heterosis over the check (Naveen) was revealed by four cross combinations viz., UHFT-10 x Solan Lalima (12.30), UHFT-55 x Solan Lalima (11.00), UHFT-9 x Solan Lalima(11.00) and UHFT-10 $x$ EC-2798
(6.15). Positive heterosis over better parent for this trait has also been reported by Rani and Veeraragavathatham (2008), Kumar et al. (2009), Kumari et al. (2010), Kumari and Sharma (2011), Ahmed et al. (2011), Singh and Sastry (2011) and Singh et al. (2012).

\section{Harvest duration (days)}

Longer harvest duration ensures the continuous supply of produce and good price of tomato for over a longer period. It also keeps a balance between the demand and supply, thereby avoiding glut in the market and fall in prices. Most of the crosses (eleven) showed significant positive heterosis over better parent for this trait, being highest in UHFT-55 x EC-2798 (15.30). Significant positive heterosis over the check was revealed by only four cross combinations viz., UHFT10 x Solan Lalima (9.22), UHFT-55 x Solan Lalima (8.25), UHFT-9 x Solan Lalima (8.25) and UHFT-10 x EC-2798 (4.61). Positive heterosis for this trait has also been reported by Thakur et al. (2004), Sharma and Thakur (2008) and Kumari and Sharma (2011).

Table.1 Analysis of variance for various horticultural traits in tomato

\begin{tabular}{|l|c|c|c|c|}
\hline \multirow{2}{*}{ Source } & \multicolumn{3}{|c|}{ Mean Sum of Squares } \\
\cline { 2 - 5 } & Replications & Genotypes & Errors & Total \\
\hline Df & 2 & 21 & 42 & 65 \\
\hline Days to first flowering & 0.73 & $23.76^{*}$ & 0.85 & 25.33 \\
\hline $\begin{array}{l}\text { Days to marketable } \\
\text { maturity }\end{array}$ & 1.29 & $34.82^{*}$ & 1.26 & 37.37 \\
\hline Average fruit weight (g) & 0.43 & $386.49^{*}$ & 2.11 & 389.03 \\
\hline Number of fruits per plant & 0.51 & $20.22^{*}$ & 1.06 & 21.78 \\
\hline Harvest duration (days) & 0.32 & $20.85^{*}$ & 1.02 & 22.19 \\
\hline Yield per plant (kg) & 0.00 & $0.62^{*}$ & 0.01 & 0.63 \\
\hline Yield per plot (kg) & 0.15 & $89.07^{*}$ & 1.27 & 90.48 \\
\hline Plant height (cm) & 3.15 & $4446.59^{*}$ & 11.93 & 4461.67 \\
\hline
\end{tabular}

*Significant at 5\% level of significance 
Table.2 Mean performance and heterotic response over Better parents (BP) and Check variety for days to first flowering in tomato and marketable maturity

\begin{tabular}{|c|c|c|c|c|c|c|c|}
\hline \multirow[t]{2}{*}{ Sr.No } & \multirow[t]{2}{*}{ Parents/crosses } & \multirow[t]{2}{*}{ Mean } & \multicolumn{2}{|c|}{$\begin{array}{c}\text { Heterotic } \\
\text { response for days } \\
\text { to first flowering }\end{array}$} & \multirow[t]{2}{*}{ Mean } & \multicolumn{2}{|c|}{$\begin{array}{l}\text { Heterotic response for } \\
\text { Marketable maturity }\end{array}$} \\
\hline & & & BP & Check & & BP & Check \\
\hline & Parents & & & & & & \\
\hline 1 & UHFT-55 & 31.20 & & & 71.43 & & \\
\hline 2 & UHFT-22 & 26.93 & & & 66.30 & & \\
\hline 3 & UHFT-9 & 33.37 & & & 74.03 & & \\
\hline 4 & UHFT-10 & 32.97 & & & 73.57 & & \\
\hline 5 & EC-2798 & 35.07 & & & 76.10 & & \\
\hline \multirow[t]{21}{*}{6} & Solan Lalima & 30.83 & & & 70.97 & & \\
\hline & Crosses & & & & & & \\
\hline & $1 \times 2$ & 28.00 & 3.96 & $-8.79^{*}$ & 67.60 & 1.96 & $-3.19^{*}$ \\
\hline & $1 \times 3$ & 31.97 & 2.46 & 4.13 & 72.37 & 1.31 & $3.63^{*}$ \\
\hline & $1 \times 4$ & 28.93 & $-7.26^{*}$ & $-5.75^{*}$ & 67.70 & $-5.23^{*}$ & $-3.05^{*}$ \\
\hline & $1 \times 5$ & 26.63 & $-14.64^{*}$ & $-13.25^{*}$ & 65.93 & $-7.70^{*}$ & $-5.58^{*}$ \\
\hline & $1 \times 6$ & 28.87 & $-6.38^{*}$ & $-5.97^{*}$ & 68.63 & $-3.29^{*}$ & -1.71 \\
\hline & $2 \times 3$ & 28.47 & 5.69 & $-7.27^{*}$ & 68.13 & 2.77 & -2.43 \\
\hline & $2 \times 4$ & 26.93 & 0.00 & $-12.27^{*}$ & 66.30 & 0.00 & $-5.06^{*}$ \\
\hline & $2 \times 5$ & 25.67 & -4.70 & $-16.40^{*}$ & 64.80 & -2.26 & $-7.20^{*}$ \\
\hline & $2 \times 6$ & 25.40 & -5.69 & $-17.26^{*}$ & 64.47 & -2.77 & $-7.68^{*}$ \\
\hline & $3 \times 4$ & 32.97 & 0.00 & $7.38^{*}$ & 73.53 & -0.05 & $5.30^{*}$ \\
\hline & $3 \times 5$ & 33.57 & 0.60 & $9.34^{*}$ & 74.27 & 0.32 & $6.35^{*}$ \\
\hline & $3 \times 6$ & 30.43 & -1.30 & -0.87 & 70.20 & -1.08 & 0.53 \\
\hline & $4 \times 5$ & 31.77 & -3.64 & 3.47 & 72.10 & -1.99 & $3.25^{*}$ \\
\hline & $4 \times 6$ & 31.90 & 3.46 & 3.91 & 72.27 & 1.83 & $3.49^{*}$ \\
\hline & $5 \times 6$ & 32.83 & $6.49^{*}$ & $6.95^{*}$ & 73.37 & $3.38^{*}$ & $5.06^{*}$ \\
\hline & Naveen (check) & 30.70 & & & 69.83 & & \\
\hline & Population mean & 30.25 & & & 70.18 & & \\
\hline & $\mathbf{S E}(\mathbf{m}) \pm$ & 0.75 & & & 0.92 & & \\
\hline & $\mathrm{CD}_{(0.05)}$ & 1.50 & & & 1.84 & & \\
\hline
\end{tabular}

*Significant at 5\% level of significance 
Table.3 Mean performance and heterotic response over Better parents (BP) and Check variety for Average fruit weight ( $\mathrm{g}$ ) and No. of fruit per plant

\begin{tabular}{|c|c|c|c|c|c|c|c|}
\hline \multirow[t]{2}{*}{ Sr.No } & \multirow[t]{2}{*}{ Parents/crosses } & \multirow[t]{2}{*}{ Mean } & \multicolumn{2}{|c|}{$\begin{array}{c}\text { Heterotic } \\
\text { response for } \\
\text { Average fruit } \\
\text { weight (g) }\end{array}$} & \multirow[t]{2}{*}{ Mean } & \multicolumn{2}{|c|}{$\begin{array}{l}\text { Heterotic response for } \\
\text { No. of fruit per plant }\end{array}$} \\
\hline & & & BP & Check & & BP & Check \\
\hline & Parents & & & & & & \\
\hline 1 & UHFT-55 & 57.73 & & & 26.30 & & \\
\hline 2 & UHFT-22 & 41.63 & & & 24.80 & & \\
\hline 3 & UHFT-9 & 72.80 & & & 28.20 & & \\
\hline 4 & UHFT-10 & 60.60 & & & 30.80 & & \\
\hline 5 & EC-2798 & 45.27 & & & 23.20 & & \\
\hline \multirow[t]{21}{*}{6} & Solan Lalima & 76.60 & & & 28.70 & & \\
\hline & Crosses & & & & & & \\
\hline & $1 \times 2$ & 55.73 & -3.46 & $-25.89^{*}$ & 29.80 & $13.31^{*}$ & -3.56 \\
\hline & $1 \times 3$ & 61.63 & $-15.34^{*}$ & $-18.04^{*}$ & 30.20 & $7.09^{*}$ & -2.27 \\
\hline & $1 \times 4$ & 65.13 & $7.48^{*}$ & $-13.39^{*}$ & 32.10 & 4.22 & 3.88 \\
\hline & $1 \times 5$ & 62.20 & $7.74^{*}$ & $-17.29^{*}$ & 31.90 & $21.29^{*}$ & 3.24 \\
\hline & $1 \times 6$ & 72.63 & $-5.18^{*}$ & $-3.41^{*}$ & 34.30 & $19.51^{*}$ & $11.00^{*}$ \\
\hline & $2 \times 3$ & 63.40 & $-12.91^{*}$ & $-15.69^{*}$ & 30.00 & $6.38^{*}$ & -2.91 \\
\hline & $2 \times 4$ & 60.77 & 0.28 & $-19.19^{*}$ & 28.40 & $-7.79^{*}$ & $-8.09^{*}$ \\
\hline & $2 \times 5$ & 52.37 & $15.68^{*}$ & $-30.36^{*}$ & 29.30 & $18.15^{*}$ & -5.18 \\
\hline & $2 \times 6$ & 46.20 & $-39.69^{*}$ & $-38.56^{*}$ & 27.40 & -4.53 & $-11.33^{*}$ \\
\hline & $3 \times 4$ & 78.70 & $8.10^{*}$ & $4.65^{*}$ & 30.80 & 0.00 & -0.32 \\
\hline & $3 \times 5$ & 75.67 & $3.94^{*}$ & 0.62 & 29.70 & 5.32 & -3.88 \\
\hline & $3 \times 6$ & 82.37 & $7.53^{*}$ & $9.53^{*}$ & 34.30 & $19.51^{*}$ & $11.00^{*}$ \\
\hline & $4 \times 5$ & 70.20 & $15.84^{*}$ & $-6.65^{*}$ & 32.80 & $6.49^{*}$ & $6.15^{*}$ \\
\hline & $4 \times 6$ & 73.87 & $-3.57^{*}$ & -1.77 & 34.70 & $12.66^{*}$ & $12.30^{*}$ \\
\hline & $5 \times 6$ & 65.97 & $-13.88^{*}$ & $-12.28^{*}$ & 32.00 & $11.50^{*}$ & 3.56 \\
\hline & Naveen (check) & 75.20 & & & 30.90 & & \\
\hline & Population mean & 64.39 & & & 30.07 & & \\
\hline & $\mathbf{S E}(\mathbf{m}) \pm$ & 1.19 & & & 0.84 & & \\
\hline & $\mathrm{CD}_{(0.05)}$ & 2.37 & & & 1.68 & & \\
\hline
\end{tabular}

*Significant at $5 \%$ level of significance 
Table.4 Mean performance and heterotic response over Better parents (BP) and Check variety for harvest duration and yield per plant

\begin{tabular}{|c|c|c|c|c|c|c|c|}
\hline \multirow[t]{2}{*}{ Sr.No } & \multirow[t]{2}{*}{ Parents/crosses } & \multirow[t]{2}{*}{ Mean } & \multicolumn{2}{|c|}{$\begin{array}{l}\text { Heterotic response for } \\
\text { days to first flowering }\end{array}$} & \multirow[t]{2}{*}{ Mean } & \multicolumn{2}{|c|}{$\begin{array}{l}\text { Heterotic response for } \\
\text { Marketable maturity }\end{array}$} \\
\hline & & & BP & Check & & BP & Check \\
\hline & Parents & & & & & & \\
\hline 1 & UHFT-55 & 36.60 & & & 1.59 & & \\
\hline 2 & UHFT-22 & 33.50 & & & 1.08 & & \\
\hline 3 & UHFT-9 & 38.50 & & & 2.07 & & \\
\hline 4 & UHFT-10 & 39.00 & & & 1.84 & & \\
\hline 5 & EC-2798 & 35.10 & & & 1.10 & & \\
\hline \multirow[t]{21}{*}{6} & Solan Lalima & 41.10 & & & 2.17 & & \\
\hline & Crosses & & & & & & \\
\hline & $1 \times 2$ & 40.10 & $9.56^{*}$ & -2.67 & 1.68 & 5.71 & $-25.44^{*}$ \\
\hline & $1 \times 3$ & 40.50 & $5.19^{*}$ & -1.70 & 1.90 & $-8.07^{*}$ & $-15.89^{*}$ \\
\hline & $1 \times 4$ & 42.40 & $8.72^{*}$ & 2.91 & 2.12 & $15.52^{*}$ & -6.03 \\
\hline & $1 \times 5$ & 42.20 & $15.30^{*}$ & 2.43 & 1.94 & $21.54^{*}$ & $-14.28^{*}$ \\
\hline & $1 \times 6$ & 44.60 & $8.52^{*}$ & $8.25^{*}$ & 2.50 & $15.16^{*}$ & $10.61^{*}$ \\
\hline & $2 \times 3$ & 40.30 & $4.68^{*}$ & -2.18 & 1.89 & $-8.65^{*}$ & $-16.42^{*}$ \\
\hline & $2 \times 4$ & 38.70 & -0.77 & $-6.07^{*}$ & 1.81 & -1.69 & $-20.03^{*}$ \\
\hline & $2 \times 5$ & 38.60 & $9.97^{*}$ & $-6.31^{*}$ & 1.53 & $38.91^{*}$ & $-32.33^{*}$ \\
\hline & $2 \times 6$ & 37.70 & $-8.27^{*}$ & $-8.50^{*}$ & 1.21 & $-44.36^{*}$ & $-46.56^{*}$ \\
\hline & $3 \times 4$ & 41.10 & $5.38^{*}$ & -0.24 & 2.47 & $19.55^{*}$ & $9.38^{*}$ \\
\hline & $3 \times 5$ & 40.00 & 3.90 & -2.91 & 2.26 & $9.31^{*}$ & 0.01 \\
\hline & $3 \times 6$ & 44.60 & $8.52^{*}$ & $8.25^{*}$ & 2.74 & $26.17^{*}$ & $21.19^{*}$ \\
\hline & $4 \times 5$ & 43.10 & $10.51^{*}$ & $4.61^{*}$ & 2.21 & $20.21^{*}$ & -2.22 \\
\hline & $4 \times 6$ & 45.00 & $9.49^{*}$ & $9.22^{*}$ & 2.48 & $14.31^{*}$ & $9.79^{*}$ \\
\hline & $5 \times 6$ & 42.30 & 2.92 & 2.67 & 2.18 & 0.35 & -3.61 \\
\hline & Naveen (check) & 41.20 & & & 2.26 & & \\
\hline & $\begin{array}{l}\text { Population } \\
\text { mean }\end{array}$ & 40.27 & & & 1.96 & & \\
\hline & $\mathbf{S E}(\mathbf{m}) \pm$ & 0.82 & & & 0.08 & & \\
\hline & $\mathbf{C D}_{(0.05)}$ & 1.65 & & & 0.15 & & \\
\hline
\end{tabular}

*Significant at $5 \%$ level of significance 
Table.5 Mean performance and heterotic response over Better parents (BP) and Check variety for Yield per plot and plant height

\begin{tabular}{|c|c|c|c|c|c|c|c|}
\hline \multirow[t]{2}{*}{ Sr.No } & \multirow[t]{2}{*}{ Parents/crosses } & \multirow[t]{2}{*}{ Mean } & \multicolumn{2}{|c|}{$\begin{array}{l}\text { Heterotic } \\
\text { response for } \\
\text { yield per hactare }\end{array}$} & \multirow[t]{2}{*}{ Mean } & \multicolumn{2}{|c|}{$\begin{array}{l}\text { Heterotic response } \\
\text { plant height }\end{array}$} \\
\hline & & & BP & Check & & BP & Check \\
\hline & Parents & & & & & & \\
\hline 1 & UHFT-55 & 19.13 & & & 155.39 & & \\
\hline 2 & UHFT-22 & 12.92 & & & 76.19 & & \\
\hline 3 & UHFT-9 & 24.81 & & & 162.54 & & \\
\hline 4 & UHFT-10 & 22.06 & & & 158.40 & & \\
\hline 5 & EC-2798 & 13.21 & & & 151.76 & & \\
\hline \multirow[t]{21}{*}{6} & Solan Lalima & 26.05 & & & 166.60 & & \\
\hline & Crosses & & & & & & \\
\hline & $1 \times 2$ & 20.22 & 5.71 & $-25.44^{*}$ & 158.08 & 1.73 & $-6.68^{*}$ \\
\hline & $1 \times 3$ & 22.81 & $-8.07^{*}$ & $-15.89^{*}$ & 152.19 & $-6.37^{*}$ & $-10.16^{*}$ \\
\hline & $1 \times 4$ & 25.48 & $15.52^{*}$ & -6.03 & 154.44 & -2.50 & $-8.83^{*}$ \\
\hline & $1 \times 5$ & 23.25 & $21.54^{*}$ & $-14.28^{*}$ & 149.16 & $-4.01^{*}$ & $-11.95^{*}$ \\
\hline & $1 \times 6$ & 30.00 & $15.16^{*}$ & $10.61^{*}$ & 152.09 & $-8.71^{*}$ & $-10.22^{*}$ \\
\hline & $2 \times 3$ & 22.67 & $-8.65^{*}$ & $-16.42^{*}$ & 72.18 & $-55.59^{*}$ & $-57.39^{*}$ \\
\hline & $2 \times 4$ & 21.69 & -1.69 & $-20.03^{*}$ & 70.14 & $-55.72^{*}$ & $-58.60^{*}$ \\
\hline & $2 \times 5$ & 18.35 & $38.91^{*}$ & $-32.33^{*}$ & 73.15 & $-51.80^{*}$ & $-56.82^{*}$ \\
\hline & $2 \times 6$ & 14.49 & $-44.36^{*}$ & $-46.56^{*}$ & 83.72 & $-49.75^{*}$ & $-50.58^{*}$ \\
\hline & $3 \times 4$ & 29.66 & $19.55^{*}$ & $9.38^{*}$ & 175.14 & $7.75^{*}$ & 3.39 \\
\hline & $3 \times 5$ & 27.12 & $9.31^{*}$ & 0.01 & 148.62 & $-8.57^{*}$ & $-12.27^{*}$ \\
\hline & $3 \times 6$ & 32.87 & $26.17^{*}$ & $21.19^{*}$ & 174.13 & $4.52^{*}$ & 2.79 \\
\hline & $4 \times 5$ & 26.52 & $20.21^{*}$ & -2.22 & 150.36 & $-5.07^{*}$ & $-11.24^{*}$ \\
\hline & $4 \times 6$ & 29.78 & $14.31^{*}$ & $9.79^{*}$ & 184.38 & $10.67^{*}$ & $8.84^{*}$ \\
\hline & $5 \times 6$ & 26.14 & 0.35 & -3.61 & 181.86 & $9.16^{*}$ & $7.36^{*}$ \\
\hline & Naveen (check) & 27.09 & & & 169.40 & & \\
\hline & Population mean & 23.47 & & & 141.81 & & \\
\hline & $\mathrm{SE}(\mathbf{m}) \pm$ & 0.92 & & & 2.82 & & \\
\hline & $\mathrm{CD}_{(0.05)}$ & 1.84 & & & 5.65 & & \\
\hline
\end{tabular}

*Significant at 5\% level of significance

\section{Yield (kg/plant and kg/ plot)}

The ultimate goal of any breeding programme is to achieve more marketable yield per unit of area. The nine cross combinations resulted in significant positive heterosis over better parent, UHFT-22 x EC-2798 (38.91) being highest. Whereas, four cross combinations viz., UHFT-9 x Solan Lalima (21.19), UHFT-
55 x Solan Lalima (10.61), UHFT-10 x Solan Lalima (9.79) and UHFT-9 x UHFT-10 (9.38) revealed significant positive heterosis over the check cultivar 'Naveen'. Positive heterosis for fruit yield was reported earlier by Gul et al. (2010), Kumari et al. (2010), Kumari and Sharma (2011), Singh and Shastry (2011), Ahmed et al. (2011) and Singh et al. (2012). 


\section{Plant height (cm)}

Tall/Indeterminate varieties are generally grown in the mid hill zone of Himachal Pradesh. Such Varieties are preferred because the growing period here coincides with monsoon rains, which leads to increased incidence of buckeye rot disease of tomato and other soil borne and foliar diseases in dwarf/determinate varieties. Also more plant height is considered desirable, because it leads to more number of branches and ultimately results in increased productivity. Four cross combinations viz., UHFT-10 $\mathrm{x}$ Solan Lalima (10.67), EC-2798 x Solan Lalima (9.16), UHFT-9 x UHFT-10 (7.75) and UHFT-9 x Solan Lalima (4.52) revealed significant positive heterosis over better parent. Significant positive heterosis over the check was revealed by only two cross combinations viz., UHFT-10 x Solan Lalima (8.84) and EC-2798 x Solan Lalima (7.36). Positive heterosis for this trait has also been reported by Singh and Asati (2011), Singh and Sastry (2011), Kumari and Sharma (2011), Ahmed et al., (2011) and Singh et al., (2012).

On the basis of heterosis studies, it is concluded that the hybrids, UHFT-9 x Solan Lalima, UHFT-10 x Solan Lalima and UHFT$55 \mathrm{x}$ Solan Lalima were found promising for most of the yield and yield components. Whereas, for earliness UHFT-22 x Solan Lalima and UHFT-22 x EC-2798 were found best, hence multilocation testing can be adopted for commercial cultivation of tomato in the potential pockets of the state.

\section{Acknowledgements}

The authors' wish to express their gratitude to Indian Institute of Vegetable Research (Varanasi, India) and Dr. Y.S. Parmar University of Horticulture and Forestry, Solan (H.P.) India for providing germplasm for conducting present experiment and providing facility to conduct the experiment.

\section{References}

Ahmed,S., Quamruzzaman, A.K.M. and Uddin, M.N., 2011. Estimate of heterosis in tomato (Solanum lycopersicum L.). Bangladesh Journal Agricultural Research 36 (3): 521-527.

Choudhary, B., Punia, R.S. and Sangha, H.S., 1965. Manifestation of hybrid vigour in $F_{1}$ and its correlation in $F_{2}$ generation of tomato (Lycopersicon esculentum Mill). Indian J. Hort. 22: 52-59.

Gomez, K.A. and Gomez, A.A., 1983. Statistical Procedures for Agricultural Research. $2^{\text {nd }}$ ed., John Wiley and Sons, New York.

Griffing, B., 1956. Concept of general and specific combining ability in relation to diallel crossing system. Australian Journal of Biological Sciences 9: 463493.

Gul, R., Rahman, H.U., Khalil, I.H., Shah, S.M.A. and Ghafoor, A., 2010. Heterosis for flower and fruit traits in tomato (Lycopersicon esculentum Mill.). African Journal of Biotechnology 9(27): 4144-4151.

Hedrick, U. P. and Booth, N., 1907. Mendelian characters in tomato. Proceedings of American Society of Horticultural Sciences 5: 19-23.

Hannan, M.M., Ahmed, M.B., Razvy, R., Karim, R., Khatun, M., Haydar, A., Hossain, M.and Roy. U.K., 2007. Heterosis and correlation of yield and yield Components in Tomato (Lycopersicon esculentum Mill.). American-Eurasian Journal of Scientific Research 2 (2): 146-150.

Kumar, Y.K.H., Patil, S.S., Dharmatti, P.R., Byadagi, A.S., Kajjidoni, S.T. and Patil, R.H., 2009. Estimation of heterosis for tospovirus resistance in tomato. 
Karnataka Journal of Agricultural Sciences 22(5): 1073-1075.

Kumari, N., Srivastava, J.P., Singh.B. and Deokaran., 2010. Heterotic expression for yield and its components in tomato (Lycopersicon esculentum Mill). Annals of Horticulture 3(1): 98-101.

Kumari, S. and Sharma, M., 2011. Exploitation of heterosis for yield and its contributing traits in tomato (Solanum lycopersicum L.). International Journal of Farm Sciences 1(2): 45-55.

Mirshamssi, A., Farsi, M., Shahriari., F. and Nemati, H., 2006. Estimation of heterosis and combining ability for yield components and crossing method. Agricultural Sciences and Technology 20(3): 3-12.

Rani, C.I. and Veeraragavathatham, D., 2008. Studies on heterosis in root knot nematode (Meloidogyne incognita) resistant hybrids in tomato (Lycopersicon esculentum Mill.). The Asian Journal of Horticulture 3 (1):4044.

Sharma, D. and Thakur, M.C., 2008. Evaluation of diallel progenies for yield and its contributing Traits in tomato under mid hill conditions. Indian
Journal of Horticultural Sciences 30(34): 236-238.

Singh, A.K., and Asati, B.S., 2011. Combining ability and heterosis studies in tomato under bacterial wilt condition. Bangladesh Journal of Agricultural Research 36 (2): 313-318.

Singh, J. and Sastry, E.V.D., 2011. Heterosis and stress susceptibility index for fruit yield and contributing traits in tomato (Lycopersicon esculentum). Indian Journal of Agricultural Sciences 81 (10): 957-966.

Singh, R.K. and Singh, V.K., (1993). Heterosis breeding in tomato (Lycopersicon esulentum Mill.). Annals of Agric Res 14:416-420.

Singh, N.B., Wani. S.H , Haribhushan, A. and Nongthombam, R., 2012. Heterosis studies for yield and its components in tomato (Solanum lycopersicum L.) under valley conditions of Manipur. Vegetos 25(2): 257-265.

Thakur, A.K, Kohil, U.K. and Joshi, A., 2004. Evaluation of diallel progeny and heterosis for yield and yield contributing components in tomato. Haryana Journal of Horticultural Sciences 33 (1-2): 106-108.

\section{How to cite this article:}

Nidhish Gautam, Manish Kumar, Amit Vikram, Sandeep Kumar and Shikha Sharma. 2018. Heterosis Studies for Yield and its Components in Tomato (Solanum lycopersicum L.) under North Western Himalayan Region, India. Int.J.Curr.Microbiol.App.Sci. 7(02): 1949-1957. doi: https://doi.org/10.20546/ijcmas.2018.702.234 